\title{
ARE WE TEACHING WHAT WE SHOULD? DILEMMAS AND PROBLEMS IN TOURISM AND HOTEL MANAGEMENT EDUCATION
}

\author{
AYSE BAS COLLINS \\ School of Tourism and Hotel Management, Bilkent University, Ankara, Turkey
}

\begin{abstract}
There is a growing demand for professionally educated and trained staff in the Tourism and Hotel Management (THM) sector as the whole industry attempts to meet expanded consumer wants and desires. This article examines the relevance of THM education from stakeholders' perspectives, namely, the THM sector, the current and graduate THM students. The following research questions were posed: 1) What are the sector representatives' perceptions regarding the effectiveness of tourism education? 2) What are the current and graduate students' perceptions regarding the effectiveness of tourism education? and 3) What recommendations can be made to improve the system? Both quantitative and qualitative methods were employed in the study. Results showed that there was an expanding need for university recognition of specialization due to new technologies and consumer maturation. Likewise, the need for an improved mix between the academic and practical experience and second language inadequacies were highlighted by joint concerns expressed by the sector representatives and the graduate students.
\end{abstract}

Tourism and hotel management education Tourism and hotel management curriculum Students' perception on tourism and hotel management education Managers' perception on tourism and hotel management education

Of all sectors of international economy, tourism shows potential for unprecedented growth. Turkey, likewise, is experiencing major growth in its Tourism and Hotel Management (THM) sector (Table 1). The national economy is becoming reliant on these incomes and, therefore, is looking for better ways to optimize existing and future resources to improve this sector. Industries tend to grow or retract based on three prime factors: capital resources combined with human resources to service a market. Future prosperity requires an improvement in at least one of these factors, capital resources, human resources, or the market. This article deals with the improvement of human resources in the THM market place. Through an improved work force, capital gains can be realized when services are stable or there is an increased market as is currently the case. 
Table 1

The Growth of International Tourism in Turkey in Selected Years Since 1990

\begin{tabular}{ccccc}
\hline Years & $\begin{array}{c}\text { Arrivals } \\
(1000 \text { people })\end{array}$ & $\begin{array}{c}\text { Change } \\
\text { Percent }^{\mathrm{a}}\end{array}$ & $\begin{array}{c}\text { Receipts } \\
(1000 \text { US } \$)\end{array}$ & $\begin{array}{r}\text { Change } \\
\text { Percent }^{\mathrm{a}}\end{array}$ \\
\hline 1990 & 5,389 & 20.9 & 2,705 & 5.8 \\
1995 & 7,726 & 15.8 & 4,957 & 14.7 \\
1996 & 8,614 & 11.5 & 5,650 & 13.9 \\
1997 & 9,689 & 13.0 & 7,008 & 23.9 \\
1998 & 9,752 & 0.6 & 7,177 & 2.4 \\
1999 & 7,464 & -23.4 & 5,193 & $-27.6^{\mathrm{b}}$ \\
2000 & 10,412 & 39 & 7,636 & 47 \\
\hline
\end{tabular}

Source: National Statistics (2000).

aBase year 1963.

${ }^{b}$ Detracted growth year due to threat of terrorism and a natural disaster (earthquake).

This current growth is faced with a shortage of trained individuals across the entire sector. In order to meet this shortfall, THM education must find ways to increase the number and quality of graduates from existing or modified programs. It must develop new programs to cope with the demand for improved services and higher quality expectations. Educational institutions must begin to assess their programs and take definitive steps for the new millennium of THM. The total educational system within a country's national boundaries must be marshaled in order to assure that each discipline is filled with qualified individuals if it is to compete on a global scale.

At a national and, frequently, international level, THM education has evolved in a heterogenous and an ad hoc manner, with limited linkages to the real or perceived needs of the THM industry (Baum, 1993). The THM industry accounts for major portions of some countries' GNP and, therefore, it behooves governmental involvement. In this sense, many governments have assisted in the development of formal THM education systems, but without sector involvement (Gaiko, Kavanaugh, \& Bokerney, 1995; Gamble, 1992; Rajan, 1989). The first step in this development is policy formulation, which identifies priorities on a national, regional, or local scale. Once THM education policy is developed, it is translated from theory to practice. THM education policy should be developed by harmonization between national policy and education policy makers (Amoah $\&$ Baum, 1997) and the industry, as a whole. A number of key industry outcomes should be expected if
THM education is successful in fulfilling its role (Baum, 1995, pp. 184-185):

- the attainment of quality service;

- employee empowerment through well-educated staff at all levels;

- effective relationship marketing, depending heavily upon empowerment;

- harmony, effective cooperation, and teamwork among THM organizations, the industry, as an entity, and the educational institutions;

- preparation for vocational mobility and added market territory through the improvement of language skills;

- $\quad$ upgrading of THM operating standards;

- recognition of the importance of sustainability of human resources policies;

- developmental policy and programs for enhancement of the THM national industry.

Unfortunately, this has not always been attained.

Along these lines, a debate exists regarding curriculum content and how to deliver this content. However, there is still a consensus that THM education curricular objectives need to balance "general education" with "careerism" or "training" (Pavesic, 1991; Wisch, 1991) by meeting industry needs (Dittman, 1994) along with international awareness in the field (Blanch, 1994; Chon, 1990). But without sector involvement it cannot fully address these needs.

Some authors suggest a holistic approach (Quinton, 1988; Riegel, 1990), whereas others discuss the importance of THM courses (O'Halloran \& O'Halloran, 1992). Cooper, Shepherd, and Westlake (1996) summarize three approaches:

- Tourism-related courses, which groom students for posts within the tourism industry, arguably stressed as being tourism training, but not tourism education.

- Courses that view tourism as an activity worthy of study in its own right.

- Courses that use tourism as an illustration to enrich traditional disciplines and subject areas. Students are not necessarily employed in the tourism industry.

There has been a considerable effort by the THM educational system to clarify the role of education 
and training when compared to the traditional view (Baum, 1995; The Chartered Institute of Marketing, 1997). This effort has shown there is not an absolute distinction between education and training. Both are continuing and a lifelong process. Having recognized the importance of these two components, the THM industry educational system has given emphasis to training by establishing "sandwich" undergraduate courses that incorporate periods of industrial placement, such as internships (Di Micelli, 1998; Hogg, 1994), in between formalized course work. Although many researches (Downey \& De Veau, 1988) on internships programs have shown there is still a gap in expectations between industry and THM education, most educational institutions have some form of industry training components. It is hoped that the program will allow interns to integrate theoretical knowledge with practical experiences through experimental learning.

Beginning the 21 st century, it is unlikely to find two programs alike anywhere in the world. However, commonly the THM education curriculum has expanded its content by including common topics such as leadership, gaming, greening, ethics, community service, institutional food service, empowerment, disability acts, quality, human ecology, and business (Bartlett, Upneja, \& Lubetkin, 1998). The addition of these topics may or may not reflect the needs of the industry. But they are an academic attempt to prepare individuals for a career in the sector.
In Turkey there exist five formal levels of education, which supports the THM learning process. The processes can be stand alone or progressive in nature. They are (see Table 2): a) secondary trade schools, b) vocational training schools, c) associate/ certificate university training schools, d) undergraduate universities, e) postgraduate university programs. It is the intent of this article to address (c), (d), and (e), not (a) or (b).

The Turkish educational system offered relatively little formal education beyond the secondary level throughout the period 1950-1979. However, since then Turkey has had a monumental growth of THM institutions of higher education. Turkey now has 53 two-year schools offering THM associate or certificate programs and 14 four-year institutions offering THM bachelorate degrees. They service 14,419 and 7102 students, respectively. Even with this increase supply of trained individuals, statistics show that only $5 \%$ of the tourism work force now possess higher education degree (National Statistics, 1999).

It should be noted that the World Tourism Organization, prior to the September 11th tragedy at the WTC, projected 1 billion people by 2010 and 1.6 billion by 2020 traveling abroad. These tourists are projected to spend upwards of US $\$ 2$ trillion. Last year Turkey entertained 10.4 million tourists and this year over 12 million tourists arrived. In order to fulfill future tourists' demands and, thereby, gain a competitive edge, highly skilled employees are needed. The economic reward will go to those companies

Table 2

The Structure of Tourism Hospitality Education in Turkey

\begin{tabular}{|c|c|c|c|c|}
\hline Level & School & Duration & Entrance & Outcome \\
\hline Vocational training & $\begin{array}{l}\text { Vocational tourism } \\
\text { training centers }\end{array}$ & 7 months & $\begin{array}{l}\text { Primary ( } 8 \text { years) and secondary school } \\
\text { ( } 3 \text { years) graduates are admitted } \\
\text { through written exam \& interview }\end{array}$ & Certificate \\
\hline $\begin{array}{l}\text { Secondary school } \\
\text { level }\end{array}$ & $\begin{array}{r}\text { Vocational Tourism \& } \\
\text { Hotel High Schools }\end{array}$ & 3 years & $\begin{array}{l}\text { Only primary school graduates are admitted } \\
\text { through written exam \& interview }\end{array}$ & Diploma \\
\hline $\begin{array}{l}\text { Pre-undergraduate } \\
\text { level }\end{array}$ & Vocational schools & $\begin{array}{l}2 \text { years after any } \\
\text { secondary school }\end{array}$ & University entrance exam & Associate degree \\
\hline Undergraduate level & University & $\begin{array}{l}4 \text { years after any } \\
\text { secondary school }\end{array}$ & University entrance exam & Bachelor's degree \\
\hline \multirow[t]{2}{*}{ Postgraduate level } & University & $\begin{array}{l}2 \text { years after a } \\
\text { bachelor's degree }\end{array}$ & Written \& oral exam & M.S. degree \\
\hline & & $\begin{array}{l}\text { Minimum } 3 \text { years after } \\
\text { a master's degree }\end{array}$ & $\begin{array}{l}\text { Written \& oral exams \& foreign } \\
\text { language exam }\end{array}$ & Ph.D. degree \\
\hline
\end{tabular}


that recognize and actively pursue better-educated employees.

Based on this economic reward there is a great demand for professionally educated and trained staffs in the THM sector. This article examines the relevance of THM education from stakeholders' perspectives, namely, the sector practitioners, current students, and graduate students. This article addresses the following research questions: 1) What are the sector representatives' perceptions regarding the effectiveness of THM education? 2) What are the current and graduate students' perceptions regarding the effectiveness of THM education? and 3) What recommendations can be made to improve the system?

\section{Methods}

\section{The Site}

The research was conducted at Bilkent University, School of THM, Ankara, Turkey. Bilkent University was the first private university to institute a 2-year and 4-year program of THM in Turkey. All course work in Bilkent is conducted in English. Every year the Turkish Higher Education Council establishes an entrance exam point system to allow entry into the universities. Bilkent University THM is listed as one of the top Turkish THM Schools and accepts only the very best students from this exam.

Bilkent University THM educational program is geared to prepare the students for a broad spectrum of businesses that constitute two prime segments of the industry: a) hotels, restaurants, resorts, country clubs, and industrial food services on the hospitality side, and b) travel agencies, tour operators, and transportation companies from the travel side. In general the curriculum prepares them through course work that concentrates on managerial skills, finance and accounting, facility operations, computer literacy, fluency in English, and competence in a second foreign language.

This article was derived from an even broader research, which examined all of the university departments.

\section{Measures and Sampling}

Both quantitative and qualitative methods were employed for data collection and analysis. The study was conducted during the 1999-2000 academic year. The relevance of education was assessed from three perspectives: current students, graduates students, and sector practitioners. The subsamples were:

1. Current student participants: The research was conducted with 250 students. The respondents were composed of all third $(N=118)$ and fourth $(N=132)$ year THM students.

2. Graduate participants: 612 students have graduated from the School of THM since 1996. All graduates were sent a questionnaire as part of the study. However, only 468 (76.5\%) graduates responded (see Table 3 for the demography breakdown of the graduates).

3. Sector organization participants: The research was conducted at 14 five-star hotels, 15 fourstar hotels, 9 restaurants, 3 catering centers, and 2 travel agencies. Within these organizations, 356 supervisors, middle and top managers, all of whom had more than 10 years of experience, were included in the study. Table 4 shows the summary of the demographic variables for the sector participants.

Data were gathered through questionnaires. Three sets of questionnaires, consisting of closed and openended questions, were prepared for each subject group. Multiple choice and Likert-type scale format (1 to 6) were used for the closed-ended questions (see Tables 5, 6, and 7 for questions).

When considering the questions posed to the three groups, they could be classified into two categories: a) demography regarding their sex, school year, employment statistics, and particulars, and b) study topic related.

The questionnaires were distributed to the current students during class hours. The other two sub-

Table 3

Summary of the Demographic Variables for the Graduates

\begin{tabular}{lrrr}
\hline Graduation Year & Female & Male & Total \\
\hline 1997 & 59 & 37 & 96 \\
1998 & 90 & 82 & 172 \\
1999 & 123 & 92 & 215 \\
2000 & 77 & 52 & 129 \\
Total & 349 & 263 & 612 \\
\hline
\end{tabular}


Table 4

Summary of the Demographic Variable for the Sector Participants

\begin{tabular}{|c|c|c|c|c|}
\hline Education Level & & Management Level & Type of Positions Held & Number of Positions $(N=356)$ \\
\hline \multirow[t]{2}{*}{ Master degree } & \multirow[t]{2}{*}{$9 \%$} & Department managers & Human resources managers & 34 \\
\hline & & Line managers & HRM training managers & 10 \\
\hline \multirow[t]{3}{*}{ University degree } & \multirow[t]{3}{*}{$65 \%$} & Supervisors & Banquet managers & 32 \\
\hline & & & Sales managers & 32 \\
\hline & & & Food \& beverage managers & 34 \\
\hline \multirow[t]{10}{*}{ High school degree } & \multirow[t]{10}{*}{$26 \%$} & & Executive chefs & 41 \\
\hline & & & Front office managers & 29 \\
\hline & & & Front office assistants & 29 \\
\hline & & & Purchasing assistants & 41 \\
\hline & & & Housekeeping supervisors & 29 \\
\hline & & & Accounting managers & 12 \\
\hline & & & Accounting supervisors & 13 \\
\hline & & & Kitchen supervisors & 14 \\
\hline & & & Travel agency managers & 2 \\
\hline & & & Travel agency supervisors & 4 \\
\hline
\end{tabular}

ject groups, graduates and the organization participants, completed the questionnaires on the Internet. Collection of data from the graduates took longer than the current students and the sector organization participants due to the fact that no comprehensive document was available to act as a locator.

The data were subjected to quantitative (descriptive) and qualitative (content) analysis. Results were integrated with the information from written documents such as department curriculum and job descriptions for various positions in the THM sector.

\section{Results}

\section{Current Students' Perception}

When considering entry into the sector after graduation, results show (Table 5) that all but $21 \%$ of the students surveyed intend to obtain employment related to THM. Those students that responded negatively cited the following reasons for not choosing to continue: establishing or joining a familyowned business in another sector, low wages, disenchantment with THM, low prestige, continuing education in a master's program, changing to another career tract, and uncertainty regarding the future of the Turkish THM industry.

A majority of the students judged the curriculum as being relevant to their future goals (83\%). Those considering the curriculum irrelevant (17\%) found fault with certain program aspects. They were: the number and nature of theoretical courses, inexperienced instructors, and insufficient course content.

Course applicability to employment needs was also judged by the students. This judgement reflected the top five subjects as being Human Resources Management (53\%), Principles of Marketing (49\%), Principles of Accounting (48\%), F\&B Management (45\%), and Microeconomics (43\%).

In the department, courses focus on managerial skills, finance and accounting, hotel and travel operations, computer literacy, fluency in English, and competency in a second foreign language. Among these courses students considered finance and accounting (32\%)-related courses, such as Calculus, Statistics, and Quantitative Decision Techniques, as being the most difficult. Continuing down this list, managerial skills (29\%) and practical application courses $(21 \%)$, such as hotel and travel operations, were also considered as being difficult. Competency in a second language (11\%) and computer literacy (7\%) rounded out the difficulty listing.

Although Bilkent is an English medium university, students are required to have a second foreign language. They may choose from German, French, Italian, Spanish, Russian, or Japanese. German $(29 \%)$ is the most popular second language due to Turkey's proximity to Europe and the fact that German tourism is the second primary country that supports Turkish tourism. The other five languages were rated as follows: French (20\%), Italian (13\%), Spanish (13\%), Russian (13\%), and Japanese (12\%). 
Table 5

Summary of the Current Students' Results $(N=250)$

1. Intend to obtain employment in THM Yes

No

$21 \%$

2. Reasons for not wanting to obtain employment in THM

Establishing or joining a family business in another sector

Low wages

Disenchantment with THM

Low prestige

Pursuing further education

Changing to another career

Uncertainty regarding the future of the Turkish THM industry

3. Curriculum is relevant to future goals

Yes

No

$83 \%$

$17 \%$

4. Reasons for curriculum irrelevance

The number and nature of theoretical courses

Inexperience instructors

Insufficient course contents

5. Course applicability to employment (top five courses)

Human resources management

Principles of marketing

Principles of accounting

Food and beverage management

Microeconomics

6. Level of course difficulty

Finance \& accounting-related courses $32 \%$

Managerial-related courses $\quad 29 \%$

Practical application courses $\quad 21 \%$

Competency in a second language $\quad 11 \%$

Computer literacy

$7 \%$

7. Most popular second foreign language

German

French

Italian

Spanish

Russian

Japanese

Based on a Likert scale from 1 being totally insufficient to 6 being totally sufficient, more than half of the students $(69 \%)$ rated instruction in these languages as being insufficient in character, because of a lack of a practice environment. Further, the majority of the students $(73 \%)$ rated the English coursework as tending to be sufficient meet the needs of THM.

Of the current practical course work Food Production Techniques, International Cuisine, Food and Beverage Management, and Rooms Division Management were viewed by more than half of the students $(55 \%)$ as being adequate. The remainder found fault with course contents and instructor interest. They also considered that certain courses were required, but were not applicable to their future interest.
Table 5 (continued)

8. Sufficiency of second foreign language (6-point scale) 1 (totally insufficient) 28\%

$2 \quad 25 \%$

$3-16 \%$

$4 \quad 12 \%$

$5 \quad 12 \%$

6 (totally sufficient) $7 \%$

9. Sufficiency of English (6-point scale)
1 (totally insufficient)

$2 \quad 8 \%$

$3 \quad 12 \%$

$4+13 \%$

$5 \quad 25 \%$

6 (totally sufficient) $35 \%$

10. Practical course work is adequate
Yes

$\begin{array}{ll}\text { Yes } & 55 \% \\ \text { No } & 45 \%\end{array}$

11. Internship was effective
Yes

$\begin{array}{ll}\text { No } & 38 \%\end{array}$

12. Complains regarding internship

No compensation

Uncomfortable \& hectic work environment

Lack of communication

Lack of orientation \& training

Negative attitude from supervisors \& colleagues

13. Priority while choosing courses

Course instructor $\quad 48 \%$

Course schedule $\quad 34 \%$

Course content $28 \%$

14. Instructor efficiency (6-point scale)
1 (totally ineffective)

$2 \quad 9 \%$

$325 \%$

$4 \quad 36 \%$

$5 \quad 26 \%$

6 (totally effective) $1 \%$

15. What would you change?
Course content

$\begin{array}{ll}\text { Course schedule } & 28 \%\end{array}$

Increase the number of practical courses $\quad 5 \%$

Reduce the total number of contact hours $\quad 7 \%$

Reduce the number of courses required for graduation $\quad 13 \%$

Change the ineffective instructors $13 \%$

16. Anything you want to add on this issue?

The industrial training periods were seen as a vital part of the educational program. Students were asked to give their opinion as to the effectiveness of the training. A majority (62\%) found it as being effective. The remaining (38\%) had specific complaints regarding the Industrial Training. It was pointed out that interns were offered little or no compensation in terms of pay, transportation, medical services, insurance, accommodations, and social activities. They further considered the work environment as being uncomfortable and hectic. Regard- 
ing their interaction with the organizations staff, they complained about the lack of communications, particularly concerning orientation and training, and a negative attitude from their supervisors and colleagues (pointing perhaps to noted friction between nondegreed and the students who would ultimately receive a degree).

When choosing courses, it was found that $48 \%$ of the students placed more importance on the instructor presenting the course, rather than the actual course content (28\%). They based this decision on the instructor's grading system, educational background, and field experience. They also noted that course schedule $(34 \%)$ played a role in their choice.

Students contended that unless classes were given by efficient instructors, it did not matter how effective the course contents were or the schedule. On a 6 -point Likert scale ( 1 being totally ineffective and 6 being totally effective), the majority $(61 \%)$ rated the department instructors in the 3-4 range. One third of the students pointed out that there were certain instructors whose courses could not be passed even with extreme effort on the students' behalf.

If presented the opportunity to change some aspect of the THM program, students said that they would change the course contents $(34 \%)$ and the schedule (28\%). They felt that the school should increase coursework that had a practical application (5\%) to the sector and more directed to real-life settings. Further, they pointed out the desire to reduce the total number of contact hours (7\%). They also said that they would change ineffective instructors $(13 \%)$ and reduce the number of courses required for graduation (13\%).

\section{Graduates' Perception}

In order to depict the actual outcome of the program, graduate students were surveyed on various aspects of both the program and the employability they had experienced after graduation (Table 6). At the time of the study $60 \%$ of the surveyed population have acquired gainful employment and of that population $87 \%$ are employed in a THM-related field.

When asked what situation awaited the graduates on completion of school, it was noted that only $13 \%$ went directly into the THM sector and $8 \%$ actually started their own THM-related business. In Turkey due to compulsory military service of all males, many employers require completion of service as a prerequisite to employment. Due to this fact, $26 \%$ of the graduate students immediately entered the military service. Further, $17 \%$ were unable to find immediate employment. The remaining graduates either joined a family-run business (19\%) or elected to start a masters program (17\%).

When surveyed as to the effect of their degree upon acquiring employment it was found that $47 \%$ of the graduates considered it totally effective. Even an additional $29 \%$ scored its effectiveness 5 on a Likert scale. An overwhelming $86 \%$ of the respondents found the program effective in the upper part of the scale.

When asked on a scale of 1 to 6 ( 1 being totally ineffective and 6 being totally effective) whether the curriculum they had attended was effective in preparing them for employment in a field-related position, $36 \%$ considered the classes as being totally effective. At the other end of the spectrum, $10 \%$ found the classes as being totally ineffective. Of the remaining amount, $40 \%$ were in the 4 and 5 range, therefore leaning toward effective, $14 \%$ were in the 2 and 3 range, leaning towards ineffective. If compared on the whole, this means $76 \%$ considered the curriculum as leaning toward effective.

The graduates were asked to rate the internship program effectiveness again on a scale of 1 to 6 , with 6 being totally effective. Out of the population, $9 \%$ found the program as being totally effective, whereas $14 \%$ considered it as totally ineffective. A composite population of $64 \%$ felt that the program tended to be effective.

Having now been faced with the real-world setting most graduates considered their English course work as tending to be totally effective (42\%). Another $48 \%$ rated English course work 4 or 5, thereby giving a strong impression that the English course work is effective. When considering the languages other than English, more than half of the graduates leaned toward ineffective (55\%); only $9 \%$ found it as being totally ineffective. Field-related course work was overwhelmingly found to be totally effective with $43 \%$. In fact, only $15 \%$ were in the realm of ineffective.

Even though most graduates found the program effective, they still had relevant complaints in regards to the program. They considered that there 
Table 6

Summary of the Graduates' Results $(N=468)$

1. Current employment situation

Employed

Unemployed

2. Current employment in THM

Yes

No

3. Situation just after graduation

Military service

Join family business

Start master program

Looking for a job

Start to work in THM sector

Start own business in THM

4. Effect of degree upon acquiring employment (6-point scale) 1 (totally ineffective)

2

3

4

5

6 (totally effective)

5. Curriculum effectiveness (6-point scale)

1 (totally ineffective)

2

3

4

5

6 (totally effective)

6. Internship effectiveness (6-point scale)

1 (totally ineffective)

2

3

4

5

6 (totally effective)

\section{$60 \%$}

$40 \%$

$87 \%$

$13 \%$

$26 \%$

$19 \%$

$17 \%$

$17 \%$

$13 \%$

$8 \%$

should be increased time spent in the internship program and that more emphasis should be placed on management courses. Further, they also pointed out the need for a second foreign language. They felt that the computer-related classes were lacking and more time should have been spent on computer application courses. When considering the instructors, they felt that there should be an increased amount of instructors that had sector experience. They also felt that the university would have been wise to employing more foreign instructors, thereby giving the students added contact time with foreigners. This would permit students to become comfortable using a foreign language and be able to interact with people of other cultures. The graduates also complained that the university's Career Development Center did little to assist them in placement before and after graduation.
Table 6 (continued)

\begin{tabular}{lr} 
7. Sufficiency in English (6-point scale) & \\
1 (totally ineffective) & $2 \%$ \\
2 & $3 \%$ \\
3 & $5 \%$ \\
4 & $9 \%$ \\
5 & $39 \%$ \\
6 (totally effective) & $42 \%$ \\
8. Sufficiency in second language (6-point scale) & \\
1 (totally ineffective) & $8 \%$ \\
2 & $7 \%$ \\
3 & $40 \%$ \\
4 & $22 \%$ \\
& \\
5 & $14 \%$ \\
6 (totally effective) & $9 \%$ \\
9. Efficiency of field related courses (6-point scale) & \\
1 (totally ineffective) & $6 \%$ \\
2 & $3 \%$ \\
3 & $6 \%$ \\
4 & $17 \%$ \\
5 & $25 \%$ \\
6 (totally effective) & $43 \%$ \\
10. Suggestions to improve the program & \\
Increased internship time & \\
More emphasis on managerial courses & \\
Efficient second language teaching & \\
More computer application courses & \\
More instructors with sector experience & \\
More foreign instructors & \\
More effective career development center & \\
11. Realization of university expectations & \\
Yes & \\
No & \\
11. Anything you want to add on this issue? & \\
Expand the list of electives & \\
\hline & \\
\hline & \\
& \\
&
\end{tabular}

The graduates were asked if their expectation had changed from entering the department until graduation. A total of $71 \%$ responded that their expectation had been met. However, they wished that they could have had opportunity to select more electives from an expanded list, even from other departments and faculties.

\section{Managers' Perception}

The results showed that managers perception of graduate employability (Table 7) were based on personal characteristics (35\%), followed by education $(33 \%)$, fluency in a foreign language $(20 \%)$, and work experience (12\%).

All managers surveyed showed a distinct preference towards graduates from universities that are based on English medium. Furthermore, 50\% of them 
Table 7

Summary of Sector Participants' Results $(N=356)$

1. Most important qualifications sought for employment Personal characteristics

$35 \%$

Education

Fluency in a foreign language

Work experience

2. Preference for English medium graduates

Yes

No

3. Necessity for a second foreign language

Yes

No

4. Necessity for a foreign degree

Yes

No

5. Necessity of computer skills

Yes

No

6. Opinion about the variety of THM education

More field-related education

At least two foreign language

More training-based curriculum

No problem with the current program

7. Preference for degree

2-year degree plus 2-year experience $\quad 57 \%$

4-year degree program

8. Long-run benefit of 4-year program graduates Yes

No

9. Problems between nonedegreed and degreed employees Yes

No

10. Advantages of working with university graduates

Easy to work with

Clever

Knowledge of foreign language

Easy adaptation

More consistent and reliable decisions

Team players

Commitment to organizational goals

More entrepreneurial and self-confident

Goal-oriented \& adaptive

11. Disadvantages of working with university graduates

Know-it-all condescending attitude

Lack stamina

Early expectation of management position

Lack of patience with hierarchy

Shallow industrial training

Lack of fluency in a second foreign language

12. Anything you want to add on this issue? insisted that a second foreign language, preferably German, was an absolute necessity for employment in the sector. Then, $85 \%$ pointed out that they did not show preference to graduates that had a foreign degree. However, they preferred graduates to have enhanced computer skills. Every one of the respondents placed computer skill as vital to employment.
It is the managers' opinion that subject matter should veer away from a general curriculum to more specific topics after the second year of the university program $(36 \%)$. The second managerial expectation was that schools should assure that students have at least two foreign languages (29\%). They also expected the schools to have courses that provide the students with training-based curriculum $(27 \%)$. Only $8 \%$ of the managers surveyed found no fault with the current system.

When considering the managers' opinion regarding which university tract was more appropriate for graduates entering the sector, they (57\%) favored the 2-year degree program plus 2-year sector experience, over a full 4-year degree program. However, along these lines, all managers agreed that, in the long run, the investment in students that do obtain a 4-year degree was possibly more beneficial and provided them with a person who had the ability to observe, manage, and control situations. In comparison to this, managers (57\%) believed that nondegreed employees caused disconnection in the service chain and tended to have animosities towards those with degrees.

Managers were surveyed as to the advantages and disadvantages of working with university graduates. Most managers found it easy to work with university graduates. They considered them as being clever, and found that their knowledge of foreign language had a positive effect on their own position as well as their place of employment. University graduates tended to adapt easily as they related their knowledge to the work setting. By relating knowledge to work setting they also made more consistent and reliable decisions. The managers also pointed out that university graduates generally were team players, which only added to their success. They understood management policy, which assured their commitment to organizational goals. They tended to be more entrepreneurial and self-confident than their nondegreed counterparts. Managers saw them as goal oriented and able to change with situations.

Yet, some managers did find problems with university graduates and were specific in their complaints. They found that some university graduates tended to have a know-it-all condescending attitude, and they lacked stamina when coping with the hectic industry/working environment. Concerning the know-it-all attitude, they concluded that 
graduates, in general, came directly out of school expecting to go into a management position. They had little patience with the hierarchy of the existing organization. Managers also considered that their industrial training was shallow and noted a particular lack of fluency in a second foreign language. Very few found no problem with the university graduates.

\section{Discussion}

Judging by the responses received, THM education is headed in the right direction. Yet, why is it then that only 5\% (National Statistics, 2000) of the sector positions are filled with university graduates? Is it purely due to economic reasons? Doesn't the sector find placement of university graduates as a value for potential return on money spent? Is it that we as educators are missing the boat or is it that the industry is missing the boat? Or is it that, number wise, the Turkish universities have not caught up with the sector's needs?

The industry seems to have been mirrored in other regions by the same statistics: low graduate count in the sector. Australia, for example, also reflects approximately 5\% graduate employment (Industry Commission, 1996). Further, only $10 \%$ of UK managers in the THM sector have a higher education degree or certificate (Purcell \& Quinn, 1996). Commonality goes even further by the fact that employers fill their needs from those people with practical experience more so than those with a university degree. It was even pointed out that the sector would prefer 2-year degree students with work experience over 4-year degree students.

If we view the students' prime complaints regarding THM education and filter out those items that we as educators can have an effect on, then the list can be narrowed down. In order to improve the students' attitude toward staying in tourism after graduation we need to address their:
a) disenchantment with the THM industry,
b) perception of low prestige associated with a THM degree,
c) concerns about the future of the THM industry, and
d) concerns regarding inexperienced instructors or inefficient course content.

Further, in reviewing the responses it is painfully apparent that the university needs to place a greater emphasis on a second language. All three groups found this aspect of THM training lacking. Because a great deal of the THM work is geared to contact with foreign clientele, more attention should be placed on this subject. If we go further into the second language, the managers preferred those with German; however, some students were unable to take German because classes were full. Education is a business, just like any other industry. We must know our market and if that market wants five white shoes we should be selling five white shoes, not three white, one black, and one red. Classes in German should be increased.

There is a consensus between both the graduate students and the managers that enhanced computer skills are a necessity for employment in the THM sector. With all of the advancement that is occurring in the information technology area, it cannot be over emphasized that this realm should be improved and continually updated.

All three groups contended that the Industrial Training should be improved. With the managers considering 2-year students that have industrial experience more desirable than those with 4-year degrees, this aspect should be improved. The internship program may need to be more intensive.

It is one thing to say, "address this" and "address that"; it is another thing to really take action on these needs. I would contend that part of the deficiency is based on our failure to stress THM as a worthy occupation with a career ladder that one must climb in order to reach fully meaningful well-paid positions respected by our peers. Oversimplification of THM for convenience of instructional matters will fail the students upon their entry into the sector, whereas overemphasis of the industrial programs also only shows students what to do, not why we do it.

The numbers beg that we prepare our students for an expanding industry. A recurring theme in other papers on this particular matter is that we are to impart on students "advanced human and conceptual skills" (Breiter \& Clements, 1996), and "the competence to develop into innovative managers to lead the industry into the 21st century" (Purcell \& Quinn, 1996).

In reality, this article contends that universities were slow in recognizing the need for trained per- 
sonnel in this industry and failed to place importance early on. The growth was so rapid that tourism and hotel operators had no choice but to take employees from the untrained ranks and now it is difficult to replace qualified nongraduate personnel with inexperienced university graduates, except solely through attrition. New resorts, hotels, restaurants, and travel agencies all want to start with a proven staff, one with a track record. They want to enhance their chances of success, not take on the risk of fresh graduates. It is hoped that this perception will change as the industry matures and the demands increase for specialist.

It is with this thought in mind that universities can do the most to a) help the sector meet its need for experienced personnel, and b) enhance students' ability to gain employment upon graduation. Most universities now have intern programs that attempt to bridge the gap from classroom to workplace (Collins, 2000). Enhancement of these programs can be realized through more practical contact time and invitations to the industry for speaker programs by which sector experience can be shared. An Industry Speaker program could be implemented to allow industry professionals to pass on managerial techniques that had served them during their career. Just the fact of passing on actual situations that had been encountered can help students' understanding of problems (Tan \& Morgan, 2001). Visiting speakers from the industry would allow employers to give universities a greater insight into their perspective.

Another effect of this program could take on two aspects, those being the "rubbing elbows" transmission of information and the formation of advisory boards. What is meant by the "rubbing elbows" aspect is that the industry speaker would exchange views, thoughts, and suggestions to academia by the sheer fact of their presence. Their presence could not go without the informal interchange with both instructors and administrators, hopefully, giving insight to their needs and concerns.

Beyond the visiting speaker program, the establishment of advisory boards consisting of those industry leaders (speakers) and educators would formalize a regular exchange that could bring about responsiveness of the educational programs to industry needs. This, in and of itself, would lend prestige within the THM sector as an academic subject worthy of study and, thereby, encourage sector em- ployment of graduates. The study agrees with Cooper et al. (1996) that we should view THM as an activity worthy of standing as an independent academic area.

The initial sector contact through industrial training may be one of the strongest learning tools. It gives the student a chance for first-hand contact with industry reality and, further, it affords the industry the "golden opportunity to try before buying" (CatesMcIver, 1999; Neuman, 1999). Industrial training should be explored for credit level course work, which would require students to maintain "lessons learned journals" and present reports at the end of work terms. It would be time intensive, but well worth the investment. The employers should also be encouraged to actively participate in assessment and report of enhancement that students in their care need.

Today's graduates must be given a clear picture of the reality. There is no better teacher than experience and education is only a clinical approach to experience. In many instances, graduates will work for and with people with far less formal education than their own. This is solely due to the fact that THM education is in its infancy. Graduates and students alike need to realize that they are on the ground floor and opportunities await those who are patient, hard working, and understand the wants and needs of a growing clientele.

There is a point on which little attention has been given. Those managers who do not have formalized education can be "drawn into the fold," so to speak, by introduction of educational programs that invite their own participation as students. These could take the form of seminars, short courses, Internet courses, or evening classes. Managers involved would find more reasons to hire graduates with whom they share knowledge than those that feel threatened by the university "know-it-all."

Universities need to prepare graduates to do a better job of selling their services. They are faced with an industry that is in a constant state of flux and unprecedented growth. To further complicate the issue, there is also a call for "increased productivity, globalization of economic competition, changing skill requirements and rapid technological advances," making "education training and continuing education of employees critical to the economic well being," not just to an industry, but in some cases to 
the economy of a whole country (DeMicco \& Williams, 1999). This is certainly the case when viewed from a Turkish perspective.

As universities go through a recognition of the changing sector and attempt to meet its needs, students (both current and graduate), along with the industry itself, are pointing to one specific item that must be addressed: the need for specialization. This study and other studies show that universities are "unable to offer much choice in the range of subject specialization" (Michael, 1999). As the industry matures, this need for specialization will increase. Specialization will alone warrant the need for the placement of university graduates. It would seem that the industry has no time to foster its own in-house training programs and is now wading its way through the specialization problem; some of the sector will succeed and some will fail. Universities must take up the banner and address specialization. They are better equipped to keep curriculum paced with technological advances.

As follow-up to this study it is felt that a round table "focus group" should be formed in order to examine the shortfalls between the industry and education process (Ritchie \& Sheehan, 2001).

In reflection on the questions posed at the beginning of this section, I have to reiterate education has not been completely responsive to industry's needs. Further, economics is the prime motivator behind graduate placement. However, as the industry comes to grips with new technologies and the demands placed on it by mature consumers, specialization is inevitable. The industry will find that it will cost them more not to have graduate employees as they compete for the consumer dollar. Lastly, industry and universities have gone in separate directions far too long and it is time we realize that we are in the same boat!

\section{References}

Amoah, A. V., \& Baum, T. (1997). Tourism education: Policy versus practice. International Journal of Contemporary Hospitality Management, 9(1), 5-12.

Bartlett, A. L., Upneja, A., \& Lubetkin, M. E. (1998). Benchmarking hospitality management curricula: A comparison of top US programs. Journal of Hospitality Tourism Education, 10(3), 41-46.

Baum, T. (1993). Human resources issues in international tourism. Oxford: Butterworth-Heinemann.
Baum, T. (1995). Managing human resources in the European hospitality industry: A strategic approach. London: Chapman \& Hall.

Blanch, G. (1994). Making the hospitality curriculum more accessible to non-native English speakers. Hospitality \& Tourism Educator, 6(2), 63-65.

Breiter, D., \& Clements, J. C. (1996). Hospitality management curricula for the 21 st century. Hospitality and Tourism Educator, 8(1), 57-60.

Cates-McIver, L. (1999). Internships and Co-op programs, a valuable combination for collegians. Black Collegian, 30, 84.

Chon, K. S. (1990). Toward a global perspective of hospitality education. Hospitality \& Tourism Educator, 2(3), 10-11.

Collins, B. A. (2000). Gateway to the real world, industrial training: Dilemmas and problems. Paper presented at the International Hospitality Industry Evolution 2001 CU2 Joint Conference in Hospitality and Tourism, January 12 14, 2001.

Cooper, C., Shepherd, R., \& Westlake. J. (1996). Educating the educators in tourism: A manual of tourism and hospitality education. The World Tourism Organization: The University of Surrey.

Di Micelli, P. (1998). Blending theory and practical experience: A hands-on approach to educating hospitality. Journal of Hospitality and Tourism Education, 10(1), 32-36.

DeMicco, F. J., \& Williams, J. A. (1999). The strategic power of partnership for university hospitality and tourism management programs. Journal of Hospitality and Tourism Education, 11(2/3), 75-78.

Dittman, D. A. (1994). Education for the industry. The Cornell Hotel and Restaurant Administration Quarterly, 35(6).

Downey, J. F., \& De Veau, L. (1988). Hospitality internships: An industry view. The Cornell Hotel and Restaurant Administration Quarterly, 29(3), 18-20.

Gaiko, S. S., Kavanaugh, R. R., \& Bokerney, G. B. (1995). Establishing a hospitality education program for Japanese students. Hospitality and Tourism Educator, 7(1), 60-62.

Gamble, P. R. (1992). The educational challenge for hospitality and tourism education. Tourism Management, March, 6-10.

Hogg, C. (1994, Spring). A foretaste of work. Human Resources, 102-106.

Industry Commission. (1996). Tourism accommodation and training (Report No. 50). Melbourne: Australian Government Publishing Service.

Michael, A. J. (1999). A new Australian approach to tourism and hospitality education. Journal of Hospitality and Tourism Education, 11(4), 30-34.

National Statistics. (2000). Ankara: Government Printing Office.

Neuman H. (1999). Internships. Career World, 27(6), 16.

O’Halloran, R. M., \& O'Halloran, C. S. (1992). Hospitality and tourism education. Relationships to the core curriculum. Hospitality and Tourism Educator, 4(4), 56.

Pavesic, D. V. (1991). Pragmatic issues in hospitality education. Hospitality and Tourism Educator, 3(2), 38-39, 49- 
51.

Purcell, K., \& Quinn, J. (1996). Exploring the educationemployment equation in hospitality management: A comparison of graduates and HNDs. International Journal of Hospitality Management, 15(1), 51-68.

Quinton, W. (1988). Responding to hospitality education needs. Hospitality and Tourism Educator, 1(1), 32-33.

Rajan, A. (1989). Vocational training scenarios for the member states of the European community. Berlin: CEDEFOP.

Riegel, C. D. (1990). Purpose, perspective and definition: Toward an encompassing view of hotel restaurants institutional education. Hospitality and Tourism Educator, 3(1), 18-19, 28-32.

Richie, J. R., \& Sheehan, L. R. (2001). Practicing what we preach in tourism education and research: The uses of strategic research methods for program design, implementation and evaluation. Journal of Teaching in Travel and Tourism, 1(1), 49-58.

Tan, J. A. C., \& Morgan, D. J. (2001). Relevance and quality in Australian tourism education: Educator and professional views. Journal of Teaching in Travel and Tourism, 1(1), 59-79.

The Chartered Institute of Marketing. (1997). Continuing professional development; committed to excellence. Maidenhead, Berkshire, July.

Wisch, R. J. A. (1991). The general education vs. careerism debate: Developing a hospitality education perspective. Hospitality and Tourism Educator, 4(1), 65-68. 